Földi Kata

\title{
Magyar származás hatásának kvalitatív és kvantitatív kutatása a kereskedelmi márkás élelmiszerek márkaválasztására Kelet-Magyarországon
}

Kata Földi: The qualitative and quantitative research of hungarian origin effect on private label food brand choice in east Hungary

\section{Summary}

Nowadays there is more and more focus on researches of food shopping behaviour, as its key role in social practices -and in the shaping of life quality after all - is inevitable due to social effects of basic re-structuring and their undisclosed nature in the post socialist countries. These social effects are still going on because of the crisis and changes in trade politics. Earlier researches more or less focus on abstract ranges, separating daily social behaviour from their solid contexts. This is why I chose East Hungary with its smaller decretionary income and purchasing power as the spatial focus of my reasearch and the method of focus group discussion and questionnarie with food shoppers in the frame of a qualitative research and quantitative research. On the other hand, one of the reasons of the timeliness of chosing this topic is that several researchers (Totth, 2012, Polya-Szucs, 2013; Szakály, 2014) and market research institutes came to the conclusion that Hungarian customers prefer products of Hungarian origin to goods from abroad if they are cheaper than their foreign equivalent. That is why for Hungarian customers cheap own brands can be a priority even over less costly imported goods.

Keywords: hungarian origin, priavate label, food, East-Hungary

\section{ÖSSZEFOGLALÓ}

Napjainkban egyre inkább aktuálissá válik az FMCG piac konkrét árucsoport vásárlási szokás kutatások középpontba állítása, mivel a napi társadalmi gyakorlatokban - végső soron az életminőség alakításában _ betöltött kulcsszerepe vitathatatlan, valamint az egykori posztszocialista országokban lezajlott - a válság és a kereskedelempolitikai váltások miatt ma is tartó - alapvető strukturális átrendeződés társadalmi hatásai és azok feltáratlansága okán. A korábbi vizsgálatok többnyire absztrakt terekre fókuszáltak, elválasztva a napi társadalmi gyakorlatokat a térbeli kontextusoktól, amelyekben zajlanak. Ezért választottam kutatásom térbeli fókuszának az alacsonyabb diszkrecionális jövedelmú és vásárlóerejú Kelet-Magyarországot. témaválasztás aktualitását másrészt az indokolja, hogy számos kutató (Totth, 2012, Pólya-Szűcs, 2013; Szakály, 2014) és piackutató intézet kutatási eredménye bizonyította, hogy a magyar vásárlók preferálják a magyar származású termékeket, ha azok ára nem haladja meg a külföldi termékekét. Ezért a termelői márkás termékeknél alacsonyabb árszínvonalú kereskedelmi márkás termékeket a vásárlók márkaválasztása során ár szempontjából előnyben részesíthetik az alacsonyabb árú import termékekkel szemben.

Kulcsszavak: magyar származás, kereskedelmi márka, élelmiszer, Kelet-Magyarország

\section{SZAKIRODALMI ÁTTEKINTÉS}

1.1. Etnocentrizmus

Kipnis és szerzőtársai (2012) szerint a fogyasztási cikkek származási országa 
jelentősen befolyásolja a fogyasztók márka attitűdjét és magatartását (BalabanisDiamantopoulos 2008; Erickson és szerzőtársai 1984; Nebenzahl-Jaffe 1996; PapadopoulosHeslop 2002; Thakor-Kohli 1996; VerleghSteenkamp, 1999).

Solomon (2006. 328. o.) szerint az etnocentrizmus tendencia, amely alapján előnyben részesítik a termékeket vagy saját kultúrájukat más országokéval szemben. Az etnocentrikus fogyasztók valószínúleg rosszul érzik magukat, ha más ország termékét vásárolják, különösen a hazai gazdaságra gyakorolt negatív hatása miatt. Lehota (2001b) szerint a kulturális zártság formája az etnocentrizmus, amely a fogyasztó azon hiedelme, hogy az importtermék vásárlása nem helyénvaló, mivel kárt okoz a hazai gazdaságnak. Az etnocentrizmus következményeként tehát a fogyasztók előnyben részesítik a saját országuk termékeit a más nemzetek termékeivel szemben.

A magyar származás szempontjából teremtett egyértelmú helyzetet az Egyes önkéntes megkülönböztető megjelölések élelmiszereken történő használatáról szóló 74/2012. (VII. 25.) VM rendelet. A megnevezések használata nem kötelező, az élelmiszer-vállalkozó egyéni döntése, hogy alkalmazza-e. Viszont amennyiben alkalmazza, akkor a terméknek meg kell felelnie a rendeletben meghatározott, alábbi követelményeknek:

A magyar termék olyan:

- növényi élelmiszer, ahol a termesztés és az ezt követő valamennyi lépés, illetve állati élelmiszer, ahol a születés, keltetés és valamennyi ezt követő lépés Magyarországon történik.

- feldolgozatlan termék, ahol a felhasznált alaptermék magyar termék, illetve feldolgozott élelmiszer, ahol valamennyi, a termék előállitásához felhasznált alapanyag magyar származású.

A hazai termék olyan feldolgozott élelmiszer, ahol a felhasznált feldolgozatlan összetevő több mint 50\%-a magyar termék és az elóállítás valamennyi lépése Magyarországon történt.
A hazai feldolgozású termék megjelölés használható, ha a feldolgozott élelmiszer előállításához felhasznált összetevők kevesebb, mint 50\%-a hazai eredetű, de az előállítás minden lépése Magyarországon történt.

Hazai termék és hazai feldolgozású termék jelölés kizárólag a feldolgozott élelmiszerek esetében értelmezhető. Alaptermékek és feldolgozatlan élelmiszerek csomagolásán ezek a megjelölések nem használhatók.

Fazekas Sándor Vidékfejlesztési miniszter a Magyar Termék Nonprofit Kft. szakmai rendezvényén (2014) kijelentette, hogy a termékrendelet 2012-es megalkotásánál kiemelt cél volt, hogy minél több magyar termék jelenjen meg a piacon, az élelmiszerek nyomon követhetők, jó minőségűek és megbízhatók legyenek.

\subsection{Kereskedelmi márka}

A kereskedelmi márka (private label brand) fogalma röviden kiskereskedő és nagykereskedő saját márkája. (Kotler-Keller 2012, 848. o.) Ezt a megfogalmazást egészítette ki Agárdi (2010 172. o.) azzal, hogy forgalmazása egy kis- vagy nagykereskedőhöz kötődik. Baltas (1997) kiterjesztette a kereskedelmi márka fogalmát, olyan márkaként értelmezve, amely a kereskedő tulajdona, ellenőrzi és kizárólagosan értékesíti.

Napjainkban a kereskedelmi márka már minőséggel is versenyez a termelői márkával, így megvásárlásával okos vásárlói magatartást követnek. (Kumar-Steenkamp 2007) LincolnThomassen (2009. 23-25. o.) szerzőpáros 4 tévhitet cáfolt meg a kereskedelmi márkával kapcsolatban. A harmadik tévhit szerint kereskedelmi márkás termékeket alacsony diszkrecionális jövedelmúek vásárolnak. Kezdetben valóban az alacsony diszkrecionális jövedelmú és nagy háztartás létszámú családok vásárolták a kereskedelmi márkás termékeket. Viszont napjainkban a kereskedelmi márkás termékeket vásárló alacsony diszkrecionális jövedelmű háztartások arányát alig lemaradva követi a magas diszkrecionális jövedelmú háztartások aránya. 
Interdiszciplináris rovat

Balló (2013) kereskedelmi márkák magyarországi FMCG piacán való elterjedését befolyásoló tényezők összegző modelljében a termékkategória jellemzői között az ár/minőségorientált kereskedelmi márkát, gyártói márkák magatartását és szezonalitást tüntette fel. Viszont nem vizsgálta a magyar származás termékjellemzőt, amely a fogyasztók vásárlói döntését befolyásoló pszichológiai tényezők közül a percepcióban fejti ki hatását.

\section{SZEKUNDER KUTATÁS}

Magyar származású kereskedelmi márkás élelmiszerre vonatkozó kutatást nem találtam szekunder kutatásom során. Ezért a magyar származásra és a kereskedelmi márkára vonatkozó kutatások eredményeit külön-külön taglalom.

\subsection{Magyar származás}

2009. nyarán a Kaposvári Egyetem Marketing és Kereskedelem Tanszéke 1000 fős országos reprezentatív felmérésének kutatási eredménye szerint kedvező kép él a magyar élelmiszerek iránt azonban az üzletek pultjaihoz érve eltúnik, abban az esetben, ha magasabb árral találkozik a magyar termékeken, korábbi morális megfontolásait félreteszi, és mindössze tízből 2-3 vásárló emeli le a hazait a polcról. Emiatt „Janus-arcú” fogyasztóról beszélhetünk. (Szakály-Polereczki, 2010.) Mivel a magyar termék preferencia magasabb ár estén harmadára csökken, ezért Szakály (2009) szerint 10-ből 3 fogyasztó tekinthető elkötelezettnek a magyar élelmiszerek vásárlása szempontjából. Hámori-Horváth (2009) kutatási eredménye szerint etnocentrikus érzelmek a termékválasztásra inkább befolyással vannak, mint az üzletválasztásra, így a széles magyar termékválaszték a hazai, és a külföldi üzletek számára is fontos versenytényező lehet. Az Ipsos 2009-es felmérése szerint egy élelmiszertermék megvásárlásakor az ár a legfontosabb szempont a fogyasztók számára, ezt követi a minőség, az akciók és a kedvelt íz, míg a termék származása az ötödik helyen állt. (MTI, 2009.) A Nielsen piackutató vállalat 2011. évi kutatása szerint tízből hat fogyasztó tartja fontosnak, hogy amikor élelmiszert vásárol, akkor magyar terméket válasszon. Törőcsik (2011) szerint 11 termékekkel kapcsolatos kifejezés illetve kifejezéspár közül a 4. legszimpatikusabb a hazai/magyar kifejezéspár lett 4,9-es átlaggal és a harmadik legkisebb szórással $(1,17)$, amely a válaszadók egyöntetű véleményére utal. Kutatási eredményei szerint komoly mozgósító erőt mutat az, ha egy termék származási helye Magyarország. A középgeneráció az idős generációval azonos mértékben reagáltak pozitívan a "hazai/magyar" jelzőkre. A 2011ben Szolnokon készített strukturált vásárlói interjú alanyok közel fele szerint az élelmiszer üzletek tulajdonosi hovatartozása mellett/helyett a termékek magyar származása fontos a vásárlóknak. A válaszadók többsége előnyben részesíti a magyar származású termékeket, még azok is, akiknél az üzlet magyar tulajdona nem jelent elónyt. (Földi 2012. 133-143. o.) Totth (2012) szerint minden eddigi kutatás azt mutatja, hogy a magyarok etnocentrikusak, azaz elónyben részesítik a hazai termékeket az import árukkal szemben. Ez igaz is, egészen a pultig, amikor választani kell a kicsit magasabb árú hazai, vagy az adott esetben alacsonyabb árú import termékek között. Ez még mindig a „Janus-arcú” fogyasztói magatartást mutatja. Pólya-Szúcs (2013) szerint néhány évvel ezelőtt nem is maga termék, a termék minősége volt a siker titka, hanem a származása adta el a terméket. Az utóbbi években a magyar termékek soha nem látott népszerűségnek örvendenek a fogyasztók körében. A fogyasztói etnocentrizmus, a „magyarságunk” az, ami megmaradt nekünk a gazdasági válság ellenére is. Természetesen erre a jelenségre a piac is intenzíven reagál: a magyar és hazai kifejezések varázsszóként múködnek, a fogyasztók számára pedig egyúttal garanciaként is szolgálnak. (Pólya-Szűcs, 2013) A magyarok 79 százaléka véli úgy, hogy ha magyar terméket vásárol, akkor munkahelyeket lehet megőrizni. Viszont majdnem ugyanennyien vannak azok is, akik túl magas árúnak tartják a hazai élelmiszereket. Ráadásul a magyar védjegyekben is csak minden negyedik vásárló bízik. Hazai fogyasztóknál 
viszont még mindig a nemzeti érzelem dönti el, hogy leveszi-e a polcokról a magyar árut, ezért tovább kell növelni a vásárlók érzelmi kötődését a magyar élelmiszerek és a védjegyek iránt. (Szakály, 2014.) Fazekas Sándor Vidékfejlesztési miniszter a Magyar Termék Nonprofit Kft. szakmai rendezvényén (2014) elmondta, hogy a vásárlók 75 százaléka kifejezetten magyar terméket keres az üzletekben, míg 5-6 évvel ezelőtt ez az arány mindössze 50 százalék körül alakult. Ismertetése szerint a vásárlók 80 százalékát érdekli a termék származása és az élelmiszerbiztonság, és a magyar lakosság 50 százaléka akkor is a magyar terméket vásárolja meg, ha az magasabb árú, mint a külföldi. A megkezdett munka eredményességét az is igazolja, hogy a kereskedelmi láncok becslése szerint a megvásárolt élelmiszerek 75-80 százaléka belföldről származik. (Fazekas, 2014.) Kecskeméti Attila, a Magyar Termék Nonprofit Kft. ügyvezető igazgatója új partnereik közül kiemelte a Metro Kereskedelmi Kft.-t, és az Auchan Magyarország Kft.-t. Ezek a kereskedelmi vállalatok a kereskedelmi márkás élelmiszereik csomagolásán feltüntetendő megkülönböztető megjelölésekre pályáztak.

\subsection{Kereskedelmi márka}

A 2011-ben Szolnokon készített strukturált vásárlói interjúk szerint az interjú alanyok többsége szereti az üzletek saját márkás termékeit. Vannak, akiknek a kereskedelmi márkás termékek szeretete üzletlánc, termékcsoport vagy kereskedelmi márka generáció (minőség és ár) függő. Az üzletek saját márkás termékeit közepes vagy alacsony árúnak, és közepes vagy megfelelő minőségűnek ítélték. (Földi, 2012. 145.)

Nielsen piackutató intézet kutatási eredményei szerint az élelmiszerek teljes hazai kiskereskedelmi forgalmából a kereskedelmi márkás termékek részaránya értékben 25 százalékra nőtt 2012-ben. (Nielsen, 2013.) Ez a részarány 26\% volt a Gfk szerint 2013-ban, amikor átlagosan 129 alkalommal (2-3 naponta) vásároltak Magyarországon kereskedelmi márkás termékeket gyakrabban, mint a „B" márkás gyártói terméket. (Tisza, 2014.) A PLMA
2014. évi nemzetközi kereskedelmi márka évkönyv jelentése szerint a kereskedelmi márka piaci részesedése nőtt Magyarországon. Planet Retail a Kereskedelmi márkák forradalma tanulmányában 2015-re a kereskedelmi márkás termék értékbeli arányát globális szinten 24\%ra becsüli. (Gregory, 2011.)

\section{PRIMER KUTATÁS}

Kutatási célom a magyar származás szerepének vizsgálata az élelmiszerek kereskedelmi márkaválasztására Kelet-Magyarországon. Először a feltáró kutatási módszer közül szekunder adatokat vizsgáltam, majd a leíró kutatási módszerek közül megfigyelés következett. Utána a feltáró kutatási módszerek közül kvalitatív kutatás keretében fókuszcsoportos interjúk készültek a kutatási cél feltárására. Végül a leíró kutatási módszerek közül internetes megkérdezést folytattam. Kutatási módszereimet az 1 . ábra szemlélteti. Jelen mú a szekunder adatok rövid összefoglalását tartalmazza. Jelen fejezet a kereskedelmi márkás élelmiszerek csomagolásán feltüntetett magyar származás jelölések megfigyelés eredményét és a fókuszcsoportos interjúk néhány kiemelt kérdés kutatási eredményét tartalmazza.

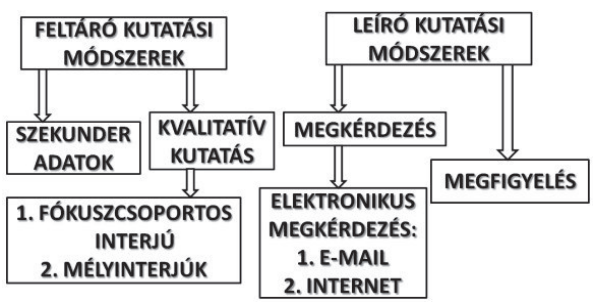

1. ábra Kutatási módszereim Forrás: Malhotra-Simon 2008 alapján

\subsection{Megfigyelés}

Primer kutatás keretében először a leíró kutatási módszerek közül megfigyelést alkalmaztam az FMCG piac minden multinacionális és magyar üzletláncában 30 kereskedelmi márkás termék csomagolásán került megfigyelésre a magyar származás jelölése 2014. május 1-15 között. A 30 kereskedelmi márkás termék tejtermék és 
tartós élelmiszerek kiválasztására a Gfk piackutató intézet kereskedelmi márkás termékek forgalmi rangsora (50-es lista) és az egyik magyar üzletlánc vevőközpontjának kereskedelmi márkás forgalmi rangsora alapján került kiválasztásra. Megfigyelés helyszínei: Tesco-Global Áruházak Zrt., Coop Hungary Zrt., Spar Magyarország Kereskedelmi Kft.,
Penny Market, CBA Kereskedelmi Kft., Lidl Magyarország, Auchan Magyarország Kft., Aldi Magyarország Élelmiszer Bt., és Reál Hungária Élelmiszer Kft. üzletei. A megfigyelés eredményét a 2 . táblázat tartalmazza.

\begin{tabular}{|l|c|c|c|c|c|c|c|c|c|}
\hline Megnevezés & Aldi & Auchan & CBA & Coop & Spar & Lidl & Real & Tesco & $\begin{array}{c}\text { Penny } \\
\text { Market }\end{array}$ \\
\hline PL & 27 & 23 & 19 & 25 & 26 & 15 & 16 & 26 & 23 \\
\hline $\begin{array}{l}\text { Termelő } \\
\text { magyar }\end{array}$ & 16 & 13 & 12 & 15 & 16 & 3 & 16 & 17 & 11 \\
\hline Magyar & 3 & 10 & 0 & 1 & 3 & 3 & 0 & 6 & 7 \\
\hline Hazai & 0 & 0 & 0 & 7 & 0 & 0 & 0 & 2 & 1 \\
\hline $\begin{array}{l}\text { Hazai } \\
\text { feldolgozású }\end{array}$ & 0 & 2 & 0 & 3 & 0 & 0 & 0 & 2 & 0 \\
\hline
\end{tabular}

1. táblázat Kereskedelmi márkás élelmiszerek csomagolás megfigyelés 30 terméken

Forrás: saját szerkesztés

Megjegyzés: $\mathrm{Pl}$ - private label = kereskedelmi márka

A kereskedelmi márkás élelmiszerek csomagolás megfigyelés eredménye szerint FMCG piac üzletláncainak (multinacionális és magyar) kereskedelmi márkás termékválasztékból hiányzó termékek: cukor, túrókrém, szendvicskrém és sűrített tej. Ezen termékekkel javaslom a kereskedelmi márkás termékválasztékot szélesíteni és mélyíteni. A megfigyelt kereskedelmi márkás élelmiszerek töredékén szerepel az önkéntes megkülönböztető megjelölés. Javaslom a kereskedelmi márkás élelmiszereken annak a megjelölésnek (magyar termék, hazai termék, hazai feldolgozású termék) feltüntetését, amelyek megfelelnek a VM rendelet (74/2012. VII. 25) előírásának, mivel a szekunder kutatás eredménye szerint a magyarok előnyben részesítik a kereskedelmi márkás magyar származású élelmiszereket, az import terméknél és termelői márkáknál.

\subsection{Kvalitatív kutatás}

Kvalitatív kutatás Babbie (2004) szerint feltárhat magyarázó értékű (változók közötti oksági) összefüggéseket és mintázatokat. Kvalitatív kutatási módszerek közül azért választottam a fókuszcsoportos interjút, mert alkalmas egy meghatározott problémakör, jelen esetben a kereskedelmi márkás élelmiszer vásárlási szokások és magyar származás szerepe témakörök mélyebb feltárására. A potenciális vásárlók által megélt jelentések empatikus feltárása és perspektíváik feltételezése megkönnyíti a vásárlói viselkedés befolyásolását (Steinar 2005, $80 . \quad$ o.) Napjainkban Steinar (2005) szerint elterjedt az interjú a vásárlói viselkedésmódok előrejelzésére és irányításra. A fókuszcsoportos interjúkban a félig strukturált megközelítést alkalmaztam, a kutatott terület főbb témáira kérdéseket készítettem elő, amelyeket az interjú alanyoknak feltettem, egy-egy kutatási témát több, egymásba fonódó kérdéssel követtem és mélyítettem (Lehota 2001a). Az interjúanalízisnek Steinar (2005) öt fő megközelítését taglalja, ezek közül a megközelítések közül alkalmaztam a jelentés kondenzációt, amivel az interjúalanyok fó mondanivalóját rövid formákká alakítottam. A kategorizáció strukturálja a kiterjedt és komplex interjúkat, áttekintést nyújt. Ezzel a módszerrel a hosszú szövegeket ábrává strukturáltam a szófelhő készítő szoftverrel. 
3.2.1. Kutatás körülményei és módszertana

A fókuszcsoportos interjúk kutatási céljai a következők voltak: az élelmiszerkiskereskedelem keresleti oldalát jelentő vásárlók véleményének mélyebb megismerése élelmiszervásárlási szokások és magyar származás szerepének témakörében valamint a kereskedelmi márkás élelmiszervásárlásról alkotott vélemények feltárása KeletMagyarországon.

A fókuszcsoportos interjúk elkészítésére 2014. májusában került sor. Előzetes telefonos időpont egyeztetés alapján 17 fókuszcsoportos interjú készült 128 élelmiszervásárlóval. A fókuszcsoportos interjú alanyok beleegyezésével hangfelvétel készült, amely a fókuszcsoportos interjú jegyzőkönyvek alapját jelentette. A fókuszcsoportos interjú alanyok lakóhelye 8 kelet-magyarországi megye (JászNagykun-Szolnok, Békés, Bács-Kiskun, BorsodAbaúj-Zemplén, Heves, Csongrád, SzabolcsSzatmár-Bereg, Pest) több mint 30 települése volt. $\mathrm{Az}$ interjú alanyok életkora 18-87 év közötti, foglalkozásukat tekintve tanulóktól, fizikai és szellemi foglalkoztatottakig valamint nyugdíjasokig vettek részt a fókuszcsoportos interjúkon. Az interjúalanyok körében mindkét nem képviseltette magát, habár a nők többségben voltak, mivel a szakirodalmi és szekunder kutatások szerint nők a fő élelmiszervásárlók Magyarországon. A fókuszcsoport alanyai szociodemográfiai ismérvek alapján számos társadalmi rétegből kerültek ki. A fókuszcsoportos interjúk feldolgozásához szófelhő módszert alkalmaztam, amelyhez a http://wordle.net weboldal szófelhő készítő programja nyújtott segítséget. A szófelhő módszer segítette a válaszok tartalomelemzését. A fókuszcsoportos interjú 4 témakörben 37 kérdést tartalmazott.

\subsubsection{Kutatási eredmények}

A származási ország élelmiszerek csomagoláson való feltüntetése az interjú alanyok többségének nagyon fontos vagy fontos, sőt volt olyan interjú alany, aki nem veszi meg a terméket, ha nem tudja, hogy honnan származik.
Számos interjú alanynak nem fontos, nem igazán fontos, vagy meg sem nézi a származási országát a megvásárolni kívánt terméknek. Ezt a véleményt az alábbi válasz szemlélteti leginkább.

Az interjú alanyok azon csoportjának, akiknek fontos a származási ország csomagoláson való feltüntetése ezt a véleményt azzal indokolták, hogy minőséget (zöldségnél és gyümölcsnél jó ízt), megbízhatóságot, biztonságot jelent. Ezt a meggyőződést foglalja össze az alábbi interjúalany nézete.

Azok számára, akiknek nem fontos a termékeken a származási ország feltüntetése azzal indokolták véleményüket, hogy a termék minősége, de elsősorban az ára (olcsó) befolyásolja a termékválasztást, és nem a származási ország. Ezt a véleményt az alábbi interjú alany foglalta össze.

$A z$ interjú alanyok többségének fontos illetve nagyon fontos az élelmiszerek magyar származása. Ezt a nézetet ragadja meg az alábbi interjú alany megfogalmazása.

Viszont markáns véleményként körvonalazódott, hogy ha a magyar élelmiszer árát magasnak ítélik, akkor inkább az alacsonyabb árú külföldi terméket vásárolják meg.

Néhány interjú alany százalékos mértékben fejezte ki a magyar származás fontosságát élelmiszer vásárláskor 20\%-tól $80 \%$-ig szóródott a fontosság értéke.

A legtöbb interjú alany semennyivel sem hajlandó többet fizetni a magyar származású élelmiszerért. Az ár viszonylatában helyettesítő termékként megjelennek az alacsonyabb árú külföldi termékek, ezt határozta meg lényegre törően az alábbi interjú alany válasza.

Számos interjú alany jövedelmétől, a termék értékétől, árától, minőségétől és árucsoporttól (pl.: zöldség, gyümölcs) tette függővé, hogy mennyivel hajlandó többet fizetni a magyar származású élelmiszerért. A magasabb árat fizetni hajlandó interjú alanyok megoszlanak a kevesebb, mint 10\%-ot és a 10-20\%-kal magasabb árat kész megfizetni vásárlókra. A magasabb ár megfizetési hajlandóság viszont jövedelem vásárlóerejének függvénye, amely 
korlátozza a vásárlók körét. Ezt fejezi ki az alábbi interjú alany vélekedése.

A legtöbb interjú alany megnézi a termék csomagolásán a magyar származás jelölését, de közel annyian nem nézik meg.

A szekunder kutatási eredményeknek leginkább ellentmondó, hogy több interjú alany bevallása szerint megnézi a csomagoláson a magyar származás jelölését, de nem befolyásolja vásárlási döntését. Néhány interjú alany a vásárlásra rendelkezésre álló idő függvényében nézi meg a csomagoláson a magyar származást, másnak szemüvegre van hozzá szüksége a csomagoláson szereplő apró betűs információk elolvasása miatt. A magyar származási országot a csomagoláson megnéző vásárlókat is érheti olykor kellemetlen meglepetés az alábbi interjú alany vélekedése szerint.

Néhány interjú alany árucsoport (pl.: tejtermékek, hús- és hentesáru) függvényében nézi meg a csomagoláson a magyar származás jelölését.

$\mathrm{Az} \quad$ interjúalanyok többségének termékválasztását befolyásolja a magyar származás, de annak mértéke változó. A legtöbb interjú alanyt nagy mértékben befolyásolja, de számos olyan fókuszcsoport résztvevő volt, akit egyáltalán nem befolyásol. Voltak olyan interjú alanyok, akiknél a befolyásolás mértéke az árutól (pl.: tojás) illetve árucsoporttól (pl.: tejtermékek) vagy kiszerelés nagyságától, ártól függ.

A válaszadók nem voltak tisztában a termék jelölések közti különbséggel.

Az interjú alanyok többsége magyar terméket vásárolna legszívesebben. Az interjú alanyok azért választanak magyar terméket, mert véleményük szerint 100\%-osan magyar, magyar alapanyagból készült magyar termelők gyártják, dolgozzák fel, csomagolják és forgalmazzák. Magyar termék vásárlásakor a termékeket biztonságosnak (elsősorban egészségügyileg), megbízhatónak és bizalom gerjesztőnek ítélik. Ezen termékek megvásárlásakor a válaszadók úgy érzik, hogy támogatják a magyar gazdaság fejlődését és a hazai gazdákat.

$\mathrm{Az}$ interjú alanyok többsége konkrét termékeket illetve árucsoportokat soroltak fel olyan élelmiszerekként, amelyek csomagolásán szerepelhet a magyar termék jelölés. Számos interjú alany úgy gondolta, hogy akkor szerepelhet a csomagoláson a magyar termék jelölés, ha az alapanyag és a feldolgozás is magyar. Addig mások szerint csak a termelésnek, előállításnak vagy alapanyagnak kell magyarnak lennie.

Így szükségesnek vélem az egyes önkéntes megkülönböztető megjelölések élelmiszereken (magyar termék, hazai termék, hazai feldolgozású termék) pontos jelentésének ismertetését elsősorban televiziós reklámban.

Volt olyan fókuszcsoportos interjú alany, aki megtévesztőnek ítélte a csomagoláson feltüntetett magyar termék jelölést az alábbi véleménye szerint:

A legtöbb interjú alanyt valamilyen mértékben befolyásolja a magyar származás a kereskedelmi márkás termékválasztáskor. A befolyásolás mértéke eltérő: nagyon, közepesen vagy csekély szinten. Az interjú alanyok véleményét a magyar származás befolyásoló hatásáról a kereskedelmi márkaválasztásra a 2. ábrán lévő szófelhő ábrázolja.

Néhány fókuszcsoport résztvevő előnyben részesíti a magyar származású kereskedelmi márkás élelmiszert. Ezt fejezi ki a két alábbi vélemény.

Ez alapján javaslom, hogy az FMCG piac kiskereskedelmi üzletláncai (magyar és multinacionális is) a kereskedelmi márkás termékek csomagolásán tûntettessék fel a magyar származást (magyar termék, hazai termék és hazai feldolgozású termék).

\section{befolyásolja}

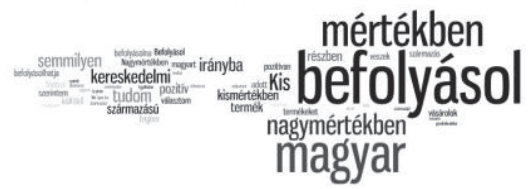

2. ábra Magyar származás befolyása a kereskedelmi márkaválasztásra

Forrás: wordle.net 


\subsection{Kvantitatív kutatás}

\subsubsection{Kvantitatív kutatás körülményei és módszertana}

\subsubsection{A minta nagysága és jellege}

A megkérdezés standardizált kérdőív alkalmazásával, online megkérdezéssel történt google drive weboldalon. A kitöltött kérdőívek száma 1399 db, a feldolgozható kérdőívek száma 1302 db volt. 97 kérdőív ugyanazokat a válaszokat tartalmazta minden kérdésre. A válaszadók közül 1117 fő intézi háztartása élelmiszer vásárlását leggyakrabban, azaz fó élelmiszer beszerzőnek minősül.

Csak ezen 1117 fő által kitöltött kérdőívek feldolgozott eredményét tartalmazza a kutatási eredmények. Szekunder kutatás és a korábbi primer kutatás eredményeim szerint is az élelmiszervásárlók több mint kétharmada nő. Ezen szociodemográfiai ismérv szerint a minta reprezentatív.

\subsubsection{Minta összetétele}

A mintában túlsúlyban vannak a nők, mivel az élelmiszervásárlást döntően nők végzik. Életkor szerinti összetétel szerint legnagyobb arányban 21-30 éves és a 31-40 éves életkorúak fejtették $\mathrm{ki}$ véleményüket. $\mathrm{E}$ két életkorcsoport véleménye meghatározó. Családi állapot szerint legjelentősebb a házastárs/élettársi kapcsolat 1 $(16,8 \%)$ vagy 2 gyerekkel $(16,6 \%)$ összesítetve $(33,4 \%)$ legnagyobb részarányban töltötték ki a kérdőívet. A egyedülállóak gyerek nélkül részaránya felülreprezentált. A háztartások tagjainak száma szerinti összetétel szerint legnagyobb arányban a fős háztartásban élők fejtették ki véleményüket. Az 1 és 4 fős háztartás létszámú válaszadók aránya megközelítőleg azonos volt. A válaszadók közül domináns volt a 18 év alatti gyermekkel nem rendelkező háztartások aránya (63,6\%). A megkérdezettek több mint egy ötödének 1 , addig alig több mint tizedének 218 év alatti gyermek tagja háztartásának. A kérdőívet kitöltők háztartásának közel 50\%-ában nincs eltartott, alig több mint negyedében egy, addig közel ötödében két eltartott van. A megkérdezettek között felülreprezentáltak a diplomával rendelkezők. Lakóhely szerint legjelentősebb részarányban Jász-NagykunSzolnok és Pest megyében élők töltötték ki a kérdőívet. E két csoport véleménye meghatározó. A kelet-magyarországi megyék szinte mindegyikéből volt kérdőív kitöltő. A kérdőív kitöltök lakóhelyének település típusánál a város és a megyeszékhely felülreprezentált. Míg a városban lakók arány meghaladja a 40\%-ot, addig a megyeszékhelyen lakók aránya megközelíti a 30\%-ot. A kérdőívet kitöltők háztartásának jövedelmi helyzete eltérő. Ezen adatok vélhetően csak jelzés értékűek, mivel az emberek valós jövedelmi viszonyaikat nem szívesen tárják fel. A válaszadók alig több mint $85 \%$-a adta meg havi nettó fajlagos jövedelmét, az átlag $119.819 \mathrm{Ft}$. A válaszadók háztartásának havi nettó egy főre jutó jövedelménél a 100.000-124.999 Ft és a 50.000-74.999 Ft közöttiek aránya megközelíti egymást.

\subsubsection{Megkérdezés, feldolgozás}

A kérdőívek feldolgozása IBM SPSS Statistics 20 programmal történt, amely megkönnyítette a matematikai - statisztikai számítások és elemzési eljárások alkalmazását.

\subsubsection{A kérdőív tartalma}

A kérdőív 30 kérdést tartalmazott, amelyek részben nyílt, részben zárt kérdések voltak. A zárt kérdéseknél törekedtem arra, hogy a megadott válaszlehetőségek minél árnyaltabban jellemezzék a válaszadók véleményét az adott témában. Ennek megfelelően zárt kérdésekre adható válaszok legtöbb esetben egyéb kategóriát is tartalmaztak, így lehetőség nyílt az önálló vélemény kifejtésére. A zárt kérdések jelentős része skálakérdés volt, amely statisztikai számítások elvégzésére nagyobb lehetőséget teremt, így a feldolgozás során módomban állt átlagot számítani és a szóródás lehetséges mutatóit is meghatározni. Egyes kérdéseknél a válaszokat hétfokozatú Likert-skála szerint határoztam meg, amely az egyetértés erősségét mérte. 
Interdiszciplináris rovat

\begin{tabular}{|l|c|}
\hline \multicolumn{1}{|c|}{ Témakör } & Kérdések száma \\
\hline Élelmiszervásárlási szokások & 7 \\
\hline Kereskedelmi márkás élelmiszervásárlási szokások & 11 \\
\hline Kereskedelmi márkás élelmiszerekkel kapcsolatos attitúdállítások (24) & 1 \\
\hline $\begin{array}{l}\text { Magyar származású kereskedelmi márkás élelmiszerekkel kapcsolatos } \\
\text { attitúdállítások (5) }\end{array}$ & 1 \\
\hline A válaszadók szociodemográfiai ismérvei & 10 \\
\hline
\end{tabular}

2. táblázat $A$ témakörök és a kérdések száma

Forrás: saját szerkesztés

A kérdéskörök eltérő számú kérdést és válaszlehetőséget tartalmaztak, amely a téma összetettségétől függött.

A válaszok feldolgozásánál a témának megfelelően alkalmaztam a statisztikai elemzó módszereket, a már említett átlag és szóródás mutatóin túl a kereszttáblák ismérveit a kapcsolat szorossága alapján is vizsgáltam. Terjedelmi korlátok miatt az egyváltozós statisztikai módszertani elemzésből csak a soha nem tervezett kereskedelmi márkás termékcsoportokra és indoklására térek ki. A többváltozós statisztikai elemzésből pedig a faktorelemzés alapján elkészített klaszterelemzésem eredményét a 6 faktor alapján K-közép eljárással elkülönített 5 klasztert jellemzem.

\subsubsection{Kutatási eredmények}

A kérdőívet kitöltők 50,4\%-a nem válaszolt arra a nyílt kérdésre, amely arra kérdezett rá, hogy mely termékcsoportból nem vásárolna soha kereskedelmi márkás élelmiszert. A megkérdezettek 10,5\%-a szerint nincs olyan árucsoport, amelyből soha nem vásárolna kereskedelmi márkás élelmiszert.

A konkrét árucsoportot megnevezők (437 fő) több mint negyede (27,7\%-a) húst, húskészítményt, hentesárut, felvágott, addig 14\%-uk kozmetikum, higiéniás és tisztálkodó szer, míg 8\%-uk műszaki-elektronikus és 6,9 \%uk tejtermék termékcsoportból nem vásárolna soha kereskedelmi márkásat.

A nyílt kérdésre adott válaszok szófelhőjét a 3. ábra szemlélteti.

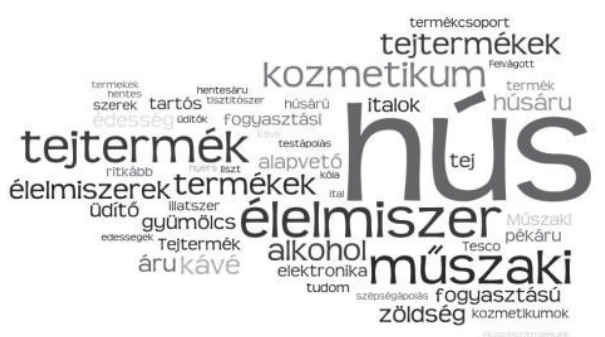

3. ábra Soha nem tervezett vásárlású kereskedelmi márkás élelmiszerek szófelhője ( $\mathrm{N}=437$ fö)

Forrás: wordle.net A kérdőívet kitöltők kevesebb, mint 40\%-a indokolta meg, hogy miért nem tervez az általa megnevezett termékcsoport(ok)ból kereskedelmi márkás élelmiszer vásárlást. A válaszadók több mint negyede minőséggel indokolta, azt frissességként, ízként illetve finomságként értelmezve. Válaszadók közel negyede megbízhatatlansággal magyarázta döntését. Megbízhatatlannak elsősorban a minőséget, a biztonságot, a hatékonyságot és az összetételt ítélték. Szintén a válaszadók közel negyede korábbi rossz tapasztalatok miatt nem vásárol az általa megnevezett kereskedelmi márkás élelmiszert. A kedvezőtlen tapasztalatot minőséggel, ízzel és finomsággal magyarázták. A válaszadók közel tizede szaküzleti, piaci és közvetlen termelői beszerzéssel igazolta a felsorolt kereskedelmi márkás élelmiszerek beszerzésének elutasítását. A válaszadók alig több mint 5\%-a magyarázta a kereskedelmi márkás élelmiszer bizonyos termékcsoportjának elutasítását a termelői márkás termékek iránti márkahűséggel.

A nyílt kérdésre adott válaszok szófelhőjét a 4. ábra illusztrálja. 


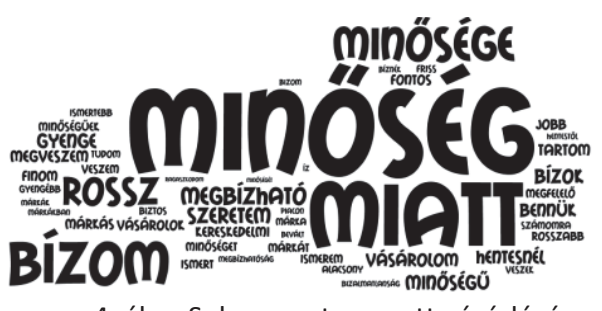

4. ábra Soha nem tervezett vásárlású

kereskedelmi márkás élelmiszerek

indoklásának szófelhője ( $\mathrm{N}=446$ fő)

Forrás: wordle.net
„A bevállt márkák ( LG, Sony,stb. ) megbízhatóbbak,

és biztos a garancia, illetve vannak kihelyezett márkaszervizeik. Egy Tesco LCD Tv esetében ez nem ennyire egyértelmü."

„A feltünően alacsony ár, kétes anyag összetételt, valamit származást sugall számomra." „ha jó a minősége és az ára, akkor jöhet"

\section{FAKTORELEMZÉS}

\begin{tabular}{|c|c|c|c|c|c|c|c|c|}
\hline \multirow{2}{*}{$\begin{array}{l}\text { Faktor } \\
\text { nevek }\end{array}$} & \multirow[t]{2}{*}{ Változók } & \multicolumn{6}{|c|}{ Faktorok } & \multirow{2}{*}{$\begin{array}{c}\text { Magyarázott } \\
\text { variancia }\end{array}$} \\
\hline & & F1 & F2 & F3 & F4 & F5 & F6 & \\
\hline \multirow{4}{*}{ 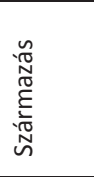 } & Magyar termelő & 0,838 & & & & & & \\
\hline & Magyar termék jelölésű & 0,889 & & & & & & \\
\hline & Hazai termék jelölésű & 0,906 & & & & & & \\
\hline & $\begin{array}{l}\text { Hazai feldolgozású } \\
\text { termék jelölésű }\end{array}$ & 0,838 & & & & & & \\
\hline \multirow{4}{*}{ 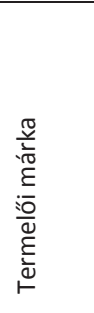 } & $\begin{array}{l}\text { Termelői márkáknál } \\
\text { gyengébb minőség }\end{array}$ & & 0,805 & & & & & \\
\hline & $\begin{array}{l}\text { Termelői márka jobb ár } \\
\text { érték aránya }\end{array}$ & & 0,786 & & & & & \\
\hline & $\begin{array}{l}\text { Termelői } \\
\text { márkapreferencia }\end{array}$ & & 0,733 & & & & & \\
\hline & $\begin{array}{l}\text { Termelői } \quad \text { márka } \\
\text { minőségével } \\
\text { megegyezik }\end{array}$ & & - & & & & & \\
\hline \multirow{4}{*}{ 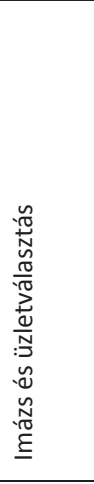 } & $\begin{array}{ll}\text { Üzletlánc } & \text { imázsát } \\
\text { befolyásolja } & \\
\text { kereskedelmi } & \text { márka } \\
\text { imázsa } & \\
\end{array}$ & & & 0,765 & & & & \\
\hline & $\begin{array}{l}\text { Üzletválasztást } \\
\text { befolyásolja } \\
\text { kereskedelmi márkája } \\
\text { jó minősége }\end{array}$ & & & 0,687 & & & & \\
\hline & $\begin{array}{l}\text { Üzlet imázsa } \\
\text { befolyásolja } \\
\text { kereskedelmi márka } \\
\text { minőség imázsát } \\
\end{array}$ & & & 0,603 & & & & \\
\hline & $\begin{array}{l}\text { Kereskedelmi márka } \\
\text { csomagolása imázsa }\end{array}$ & & & 0,560 & & & & \\
\hline \multirow{2}{*}{ 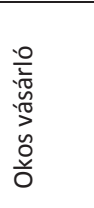 } & $\begin{array}{l}\text { Kereskedelmi márkás } \\
\text { élelmiszereket az okos } \\
\text { vásárlók vásárolják. }\end{array}$ & & & & 0,890 & & & \\
\hline & $\begin{array}{l}\text { Aki sok kereskedelmi } \\
\text { márkás } \\
\text { vásárol okos vásárló }\end{array}$ & & & & 0,887 & & & \\
\hline
\end{tabular}




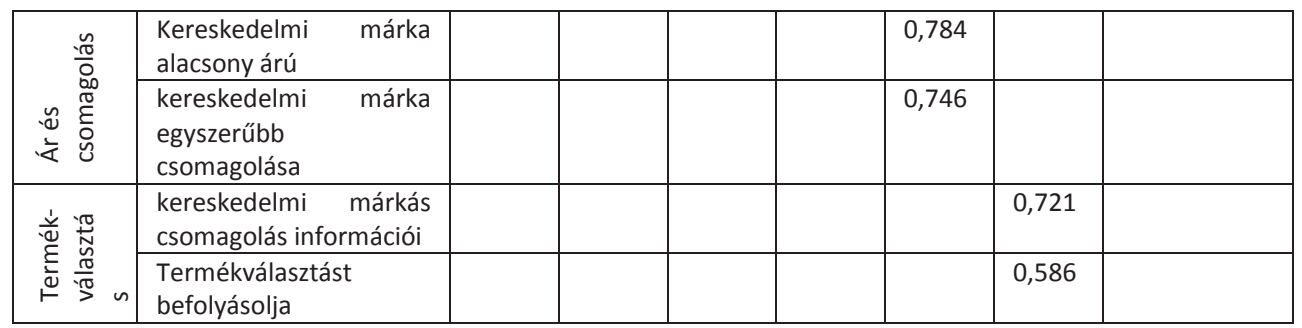

3. táblázat A csoportképzéshez használt (rotált) faktorstruktúra (principal component method), $\mathrm{KMO}=$, magyarázott variancia \%, kommunalitások, rotáció: varimax)

Forrás: saját szerkesztés SPSS output alapján

\section{KLASZTERELEMZÉS}

A termékválasztás függetlenek $(24,1 \%)$ körében enyhe túlsúlyban vannak a férfiak, egyedülállók gyerek nélkül és 1 gyerekkel valamint házastársi/élettársi kapcsolatban élők 1 gyerekkel. A háztartás létszáma tekintetében a 3 és 5 fősek jellemzik, 1 vagy 318 éves kor alatti taggal, 0,1 vagy 4 fő eltartottal. Ez a vásárlói csoport alacsony iskolai végzettséggel jellemezhető, elsősorban általános iskolai vagy ennél alacsonyabb végzettséggel vagy szakmunkás bizonyítvánnyal rendelkeznek
Békés vagy Csongrád megyei falusi vagy községi lakóhellyel rendelkeznek.

Kereskedelmi márkaválasztását legkevésbé a csomagoláson lévő információk, üzletlánc illetve üzletlánc valamint kereskedelmi márka imázsa befolyásolják. Kereskedelmi márkás élelmiszer ára, csomagolása és származása átlag alatti szinten befolyásolja ezen vásárlói csoport vásárlását. Kis mértékben átlag feletti szinten befolyásolja a termelői márka (minősége, árérték aránya, preferenciája) és némileg átlag feletti szinten befolyásolja az okos vásárlói attitűd kereskedelmi márkás élelmiszerválasztásukat.

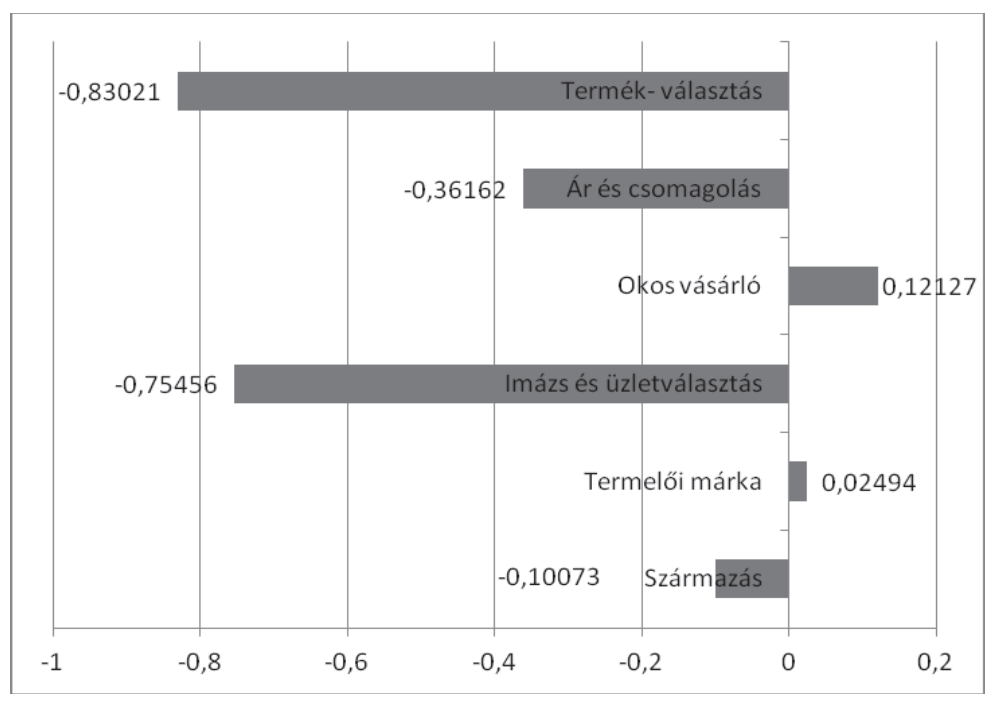

4. ábra Termékválasztás függetlenek

Forrás: saját szerkesztés SPSS output alapján 
Földi Kata: Magyar származás hatásának kvalitatív és kvantitatív kutatása a kereskedelmi márkás ...

A származásfüggetlen (16\%) kereskedelmi márkás élelmiszer vásárlói csoportban felülreprezentáltak a nők, házastársi/élettársi kapcsolatban gyerek nélkül vagy 2 gyerekkel. A családi állapotból adódóan a háztartás létszáma 1, 2, 4 vagy 6 fös. Enyhe túlsúlyban vannak 18 év alatti gyermek és eltartott nélküli háztartások. A vásárlói csoport iskolai végzettségére az eklektikusság jellemző, ugyanis a több diplomás végzettségtől kezdve szinte minden végzettségi szint enyhén felülreprezentált. Lakóhelyre Bács-Kiskun, Békés, Szabolcs-Szatmár-Bereg és Pest megye jellemző, amely megyékben vagy községben vagy nagyvárosban laknak. Jelentősen átlag alatt befolyásolja őket a termék származása (magyar, magyar, hazai vagy hazai feldolgozású termék jelölés). Némileg átlag alatti az okos vásárlói attitűd befolyásoló szerepe. Kis mértékben átlag felett befolyásolja őket a termékválasztási tényezők, némileg befolyásolják a kereskedelmi márkás élelmiszerek ára és csomagolása valamint termelői márka. A leginkább átlag feletti az imázs-(üzlet, üzletlánc, csomagolás) és üzletválasztást befolyásoló szerepe a kereskedelmi márkás termék minőségének.

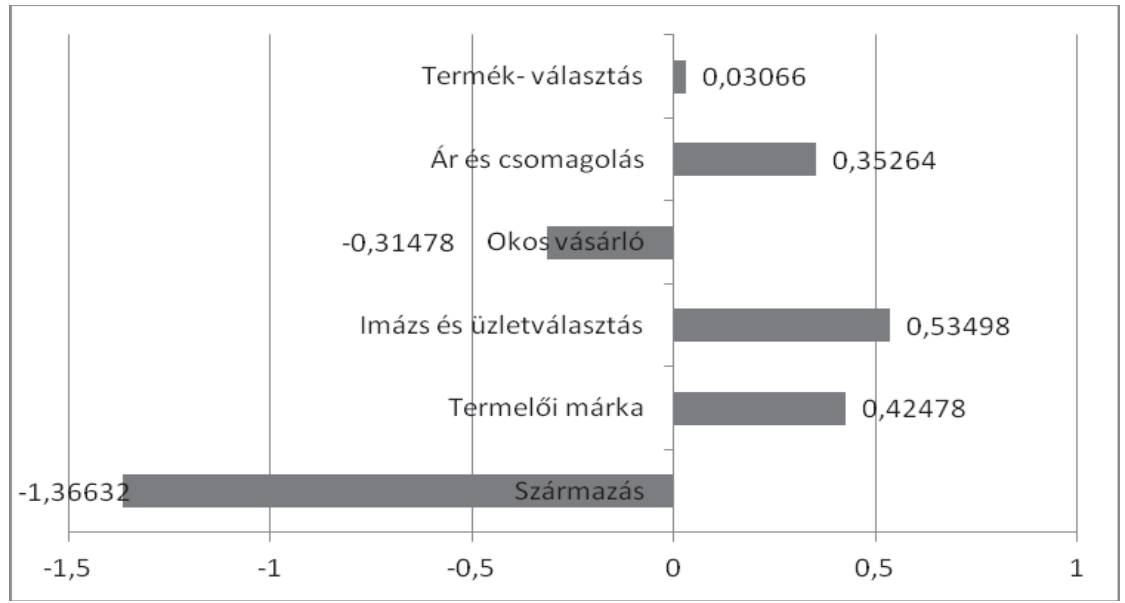

5. ábra Származásfüggetlenek

Forrás: saját szerkesztés SPSS output alapján

Az Anti smart shoppers (20,2\%) körében enyhe túlsúlyban vannak a férfiak, az egyedülállók 1 gyerekkel, vagy házas/élettársi kapcsolat gyerek nélkül, 1 vagy 2 gyerekkel. Ezen családi állapotokból adódóan az 1, 2 vagy 4 személyes háztartás jellemző 1 vagy 2 fő 18 év alatti gyermekkel és ezzel megegyező eltartotti számmal. Iskolai végzettség szempontjából érettségi és főiskolai, egyetemi diploma a sajátossága. Bács-Kiskun, Csongrád, Békés, Heves és Pest megyei lakóhelyűek némi túlsúlyban vannak, városi és községi településtípusú lakóhelyen élnek. A legnagyobb eltérés és ellentétes kereskedelmi márkás élelmiszervásárlói magatartás az átlagtól az okos vásárlói attitúd szempontjából vonatkozik. Némileg átlag alatti a kereskedelmi márkás élelmiszerválasztásnál az ár és csomagolás szerepe. Kissé átlag alattiak a termékválasztási tényezők és a termelői márka befolyásoló hatása. Jóval átlag feletti az imázs (üzletlánc, üzlet, csomagolás) és az üzletválasztást befolyásoló kereskedelmi márkás élelmiszer minősége tényezők. 


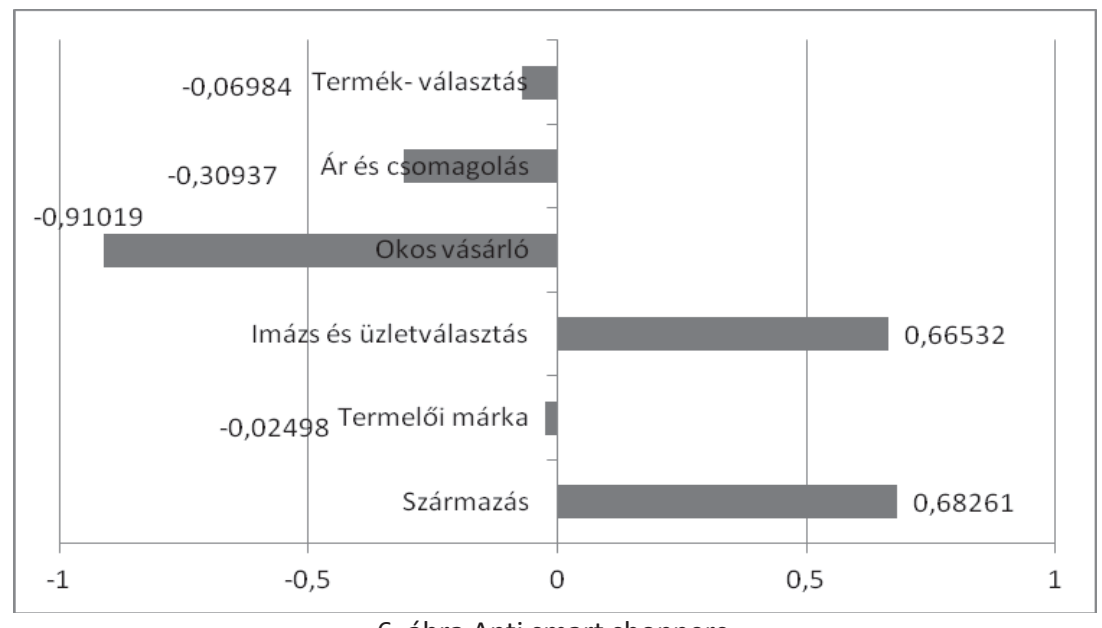

6. ábra Anti smart shoppers

Forrás: saját szerkesztés SPSS output alapján

A termékorientáltak (11,4\%) körében túlsúlyban vannak a nők, egyedülállók gyerek nélkül, 1 vagy 2 vagy 3 vagy több gyermekkel, 1 , 4, 5 vagy 6 személyes háztartásban 2 vagy 3 fó 18 éven aluli. A háztartásban az eltartottak számát tekintve túlsúlyban van 3 vagy 4 fő.

Magas iskolai végzettség felülreprezentált, ugyanis minimum technikus/szakmenedzser, menedzser (felsőfokú szakképzés), de főiskolai, egyetemi diplomával vagy több diplomával rendelkezők alkotják ezt a vásárlói csoportot.
Lakóhelyet tekintve Jász-Nagykun-Szolnok és Heves megyei nagyváros vagy megyeszékhely jellemző a csoportra. Imázs (üzletlánc, üzlet, csomagolás) üzletválasztás tényezője jelentős mértékben átlag alatti. Termelői márka és okos vásárlói attitűd nagy mértékben átlag alatti.

Nagy mértékben átlag feletti az ár és csomagolás és jelentős mértékben átlag felettiek a termékválasztási tényezők befolyásoló hatása a kereskedelmi márkás élelmiszerválasztásra.

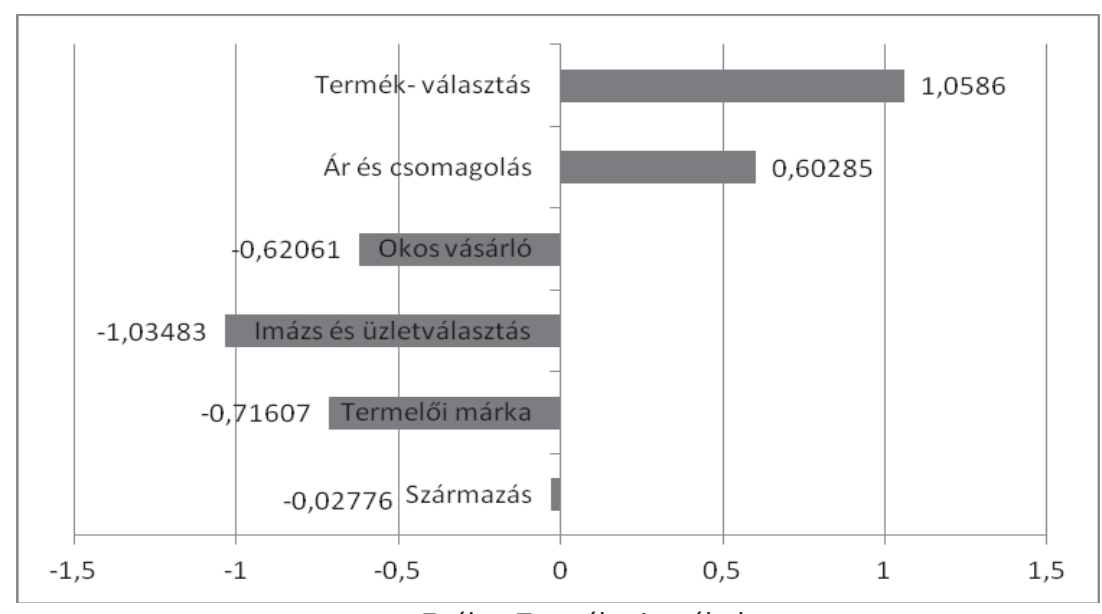

7. ábra Termékorientáltak

Forrás: saját szerkesztés SPSS output alapján 
$\mathrm{Az}$ etnocentrikus smart shoppers $(28,3 \%)$ körében enyhe túlsúlyban vannak a férfiak, jelentős túlsúlyban vannak az egyedülállók 2, 3 vagy több gyermekkel. Enyhe túlsúlyban vannak a 3 és 5 fös háztartások, 0 vagy 1 fő 18 év alatti gyermekkel, és 1 vagy 3 fő eltartottal. Iskolai végzettség szempontjából enyhe túlsúlyban vannak technikus/szakmenedzser, menedzser (felsőfokú szakképzés) iskolázottságúak. Enyhe túlsúlyban vannak a Jász-Nagykun-Szolnok megyeiek, jelentős túlsúlyban vannak a BácsKiskun, Hajdú-Bihar és Nógrád megyeiek. Lakóhelyük típusánál enyhe túlsúlyban vannak a megyeszékhelyen, városban és falun élők.
Az okos vásárlói attitűd jelentősen átlag feletti, míg a származás és a termékválasztást befolyásoló tényezők nagy mértékben átlag felettiek. Némileg átlag felett befolyásolja az imázs (üzletlánc, üzlet, csomagolás) és üzletválasztást befolyásoló kereskedelmi márkás élelmiszer minősége. A kereskedelmi márkás élelmiszer ára, csomagolása és a termelői márka kis mértékben átlag felett befolyásolja a kereskedelmi márkás termékválasztást.

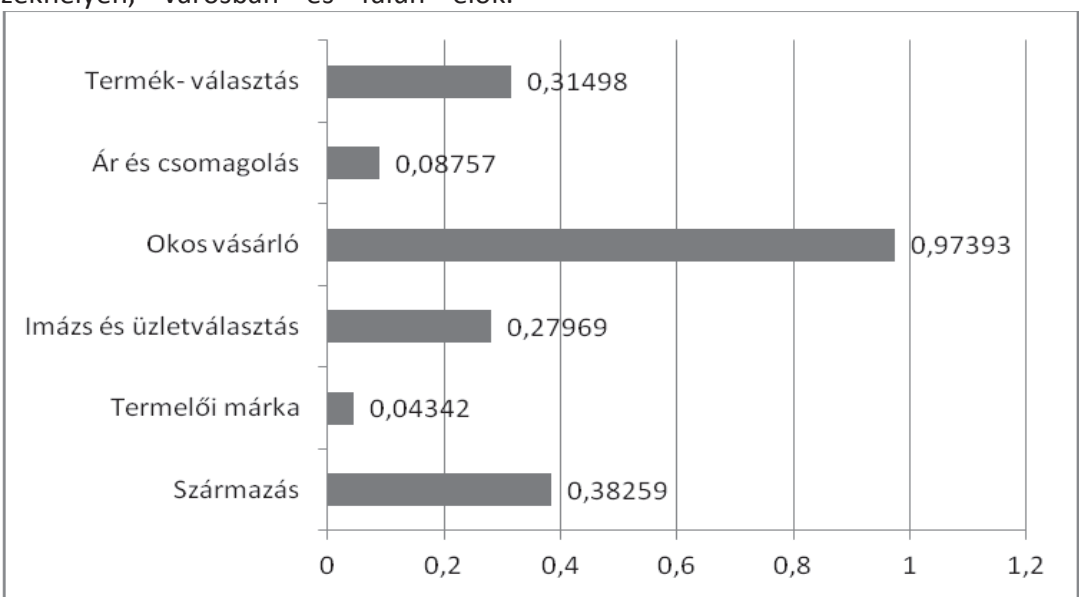

8. ábra Etnocentrikus smart shoppers

Forrás: saját szerkesztés SPSS output alapján

\section{KÖVETKEZTETÉSEK, ÖSSZEGZÉS}

A magyar származású kereskedelmi márkás élelmiszerek a márkaválasztás két kényezőjét is ötvözik, a megfelelő ár-érték arányt és a magyar származást. Így az alacsony diszkrecionális jövedelmú vásárlók többletkiadás nélkül vásárolhatnak magyar származású élelmiszereket. Szekunder és primer kutatás eredményei alapján javaslom az FMCG piac multinacionális és magyar kiskereskedelmi üzletláncainak is, hogy az egyes önkéntes megkülönböztető megjelölések élelmiszereken történő használatáról szóló 74/2012. (VII. 25.) VM rendelet szerinti 3 termék jelölés (magyar termék, hazai termék, hazai feldolgozású termék) közül azt tüntettessék fel a gyártókkal a csomagoláson, amelyik VM rendelet szerinti előírásnak a termék megfelel. A kereskedelmi márkás élelmiszerek megvásárlásával a vásárlók (kedvező ár-érték arány és magyar származás) előnyöket realizálják, és az FMCG piac kiskereskedelmi üzletláncai növekvő forgalomra és nyereségre számíthatnak. 


\section{FELHASZNÁLT SZAKIRODALOM}

[1] Balló Zs. (2013): A hazai kereskedelmi márkák vásárlói magatartását befolyásoló tényezőinek vizsgálata a napi fogyasztási cikkek piacán. Ph.D Disszertáció Gödöllő: Szent István Egyetem Gazdálkodás és Szervezéstudományok Doktori Iskola

[2] Egyes önkéntes megkülönböztető megjelölések élelmiszereken történő használatáról szóló 74/2012. (VII. 25.) VM rendelet

[3] Fazekas S. (2014): közös érdek a védjegyhasználat bővítése letöltési dátum: 2014. 05. 20

[4] http://www.elelmiszer.hu/friss_hirek/cikk/fazekas_kozos_erdek_a_vedjegyhasznalat_bo vitese?utm_source=newsletter\&utm_medium=elelmiszer_online_napi_hirlevel\&utm_ca mpaign $=12003$

[5] Földi K. (2012): A fogyasztói üzletválasztási döntések az élelmiszerorientált kiskereskedelemben Ph.D Disszertáció Pécsi Tudományegyetem Közgazdaságtudományi Kar Regionális Politika és Gazdaságtan Doktori Iskola

[6] Kipnis E. - Kubacki, K. - Broderick, A. J. - Siemieniako, D. - Pisarenko, N. L. (2012): They don't want us to become them': Brand Local Integration and consumer ethnocentrism Journal of Marketing Management, 28, 7-8, 836-864. o.

[7] Nielsen (2013): Lassult a kereskedelmi márkák piaci részesedésének növekedése az első félévben

Kereskedelmi márkás élelmiszerekkel fél év alatt mintegy 168 milliárd forint forgalmat értek el idén a boltok. Diszkontban nőtt és továbbra is kiemelkedik a kereskedelmi márkák piaci részesedése. Hírvilág, letöltés dátuma: 2014. 03.28. http://hu.nielsen.com/site/20130828.shtml

[8] PLMA (2014): Private label market share over 30\% in 15 countries, PLMA's 2014 International Private Label Yearbook reports Amsterdam, 10 June 2014. 06. 10. letöltési dátum: 2014. 07. 14. http://www.plmainternational.com/news-update

[9] Pólya Éva - Szúcs Róbert Sándor (2013): Divat lett a magyar termék Egy „kis plusz” mindenre képes lehet 2013. május 19. Élelmiszer szakfolyóirat weboldala letöltési dátum: 2013. 12. 09. http://www.elelmiszer.hu/friss_hirek/cikk/divat_lett_a_magyar_termek

[10] Szakály Z. - Polereczki Zs. (2010): „Janus-arcú” fogyasztók. 2010. március 25. letöltés dátuma: 2014.

26.http://www.elelmiszer.hu/fmcg_szakmai_hirek/cikk/_janus_arcu_fogyasztok_2

[11] Szakály, Z. (2014): Szeretik mégsem kelendő. 2014. letöltés dátuma: 2014. 07. 14. http://www.amagyartermek.hu/hirek/144/

[12] Tisza A. (2014): Gfk 2014: Ismét enyhén nőtt a kereskedelmi márkák részesedése a napi fogyasztási cikkek piacán Sajtószolgálat, letöltés dátuma: 2014. 05.31. http://www.gfk.com/hu/documents/20140508_gfk\%20a\%20kereskedelmi\%20m\%C3\%A1 rk\%C3\%A1kr\%C3\%B3l.pdf

[13] Toth, Gedeon (2012): Jó a magyar, ha nem kerül sokba - Élelmiszer klub konferencia 2012. 2012. április 3. letöltés dátuma: 2013. április 10. http://www.kreativ.hu/marketing/cikk/jo_a_magyar_ha_nem_kerul_sokba 